\title{
Research on Financial Support of New Countryside Construction in China \\ Nisi $\mathrm{Ji}^{1, \mathrm{a}}$ \\ ${ }^{1}$ Business Institute, Shandong University at Weihai, China \\ a893437642@qq.com
}

Keywords: Economic structure; Financial support; New rural construction; Urbanization

\begin{abstract}
The cap's 13th Five-Year comprehensive plan put forward a major historic task of building a new socialist countryside. This is the comprehensive implementation of urban and rural development to increase industrial agriculture, move the city to support the countryside, accelerate urbanization and narrow the gap between urban and rural areas. To solve the "three rural issues", the comprehensive construction of a well-off society, has a very important strategic role to ease the contradiction of China's rural and urban economic structure. In the process of building a new socialist countryside, the financial policy, as an important means of macroeconomic regulation and control, should play a leading role in solving the effective allocation of funds. Due to various factors affected by the current supply of rural financial market constraints, system defects and environmental constraints, there is a large gap between the level of the existing rural financial services and the requirements of the new rural construction which is to be improved urgently.
\end{abstract}

\section{Introduction}

With the accelerated pace of rural construction, the agricultural structure adjustment and agricultural industrialization are becoming more and more important .The financial demand for agriculture and rural infrastructure construction is increasing. While from the county Financial support, however, is clearly lagging behind. First of all, the credit funds for rural construction need to be paid cannot be guaranteed. Taking the county for example, the county rural financial network is Ninety-one by 2004 and reduced to 63 places in 2009. A great deal of money is needed. Secondly, The rural financial services are backward. The rural credit cooperatives, electronic bills and backward system of payment and are in low level, there only exists the traditional deposit and loan business, service less varieties and single business. It is difficult to meet the increasingly diversified demand for services in rural construction.

\section{The Straitened Circumstances of Financial Supporting Construction}

\section{The Blackness of Services in Agricultural Finance}

Before, our country basically established the rural cooperative finance as the main part of commercial finance and government Strategic Finance .The Agricultural Development Bank has a narrow scope of business and has no function Branch. Agricultural Development Bank has been established for more than ten years. Its business has always been better than agricultural field. The credit support of the industry is limited to the circulation of agricultural products. Without getting involved in agricultural production. Therefore, the Agricultural Development Bank has become a "purchasing Bank of agricultural products".

\section{A large Amount of Money Flows to Large and Medium-Sized Cities}

The current postal savings system makes a large number of regional funds flow from urban to city. It is becoming an important channel for diverting rural funds avenue. Postal savings and remittance offices are located in rural grassroots townships, there exists a large number of financial institutions in china. From this perspective, it is richly endowed by nature geographical advantage, but because of the situation, farmers will sell agricultural products capital and migrant workers who repatriate funds to maximize as a huge reservoir, not only into the rural capital, but also result in postal savings growth faster. It also accelerate the outflow of funds in rural areas the situation. 
The Difficult for Farmers to Apply for Agricultural Loan Guarantees and Credit Loans With the development of rural economy, farmers' production and living conditions have been improved. The majority of farmers will not be satisfied with the past "simple reproduction". At present, the rural credit cooperatives in rural areas are becoming more and more difficult to meet the needs of farmers' "extended reproduction". To meet the demand for more funds, credit loans will increase, and rural credit cooperatives need to bear more loan risk, which is so many credit cooperatives do not want to see.

\section{The Strategy to improve the financial support for New Rural Construction Countermeasures}

\section{Increasing the Policy Support for Rural Financial Institutions}

One is to expand the scope of the policy of supporting agriculture policy banks, in addition to providing financial support for the National Grain Reserve, should also provide strong financial support for rural infrastructure construction, ecological environment construction, comprehensive agricultural development and promoting the process of agriculture industrialization, strengthen the policy of supporting agriculture duty. Two is to promote the reform of rural credit cooperatives. We should give full play to the role of rural credit cooperatives as the main force in supporting agriculture, and improve the management of small credit loans for rural households. Three is to encourage local commercial banks to carry out the "ten base, ten farmers" loans and "order agriculture", to solve the large-scale demand for credit funds for agricultural industrialization. Business tax is levied on credit and tax relief is halved. Four is the legal obligation of rural financial institutions should make clear all, under the premise of ensuring the safety of funds, must be a certain proportion of new deposits to support local farmers, the development of private enterprises, and student consumption. The five is to realize the virtuous circle of the postal savings bank funds from "agriculture" and "use it to agriculture", and establish the mechanism of rural capital feed back flow. The postal savings bank is allowed to sign large agreement deposits with the rural credit cooperatives or the agricultural issues, and the funds shall be put into the agricultural or rural areas by the rural credit cooperatives or the agricultural issues.

\section{Improving the Rural Financial Operational Environment}

First, government departments should build society harmonious society and the new socialist countryside which attach great importance to the rural financial. We should actively change the functions of the government, and strive to create a clean and efficient government environment and public affairs. The positive and transparent judicial environment provides better services for financial institutions. As to rural cultural construction, we should strengthen the construction of rural credit system. Three is the rural insurance system into the rural financial system construction framework, and establish a perfect "three rural" insurance compensation mechanism. We will carry out pilot programs for policy agricultural insurance and set up insurance mechanisms for agricultural loans in rural areas. Funded by the state and local governments, the establishment of specialized agricultural insurance company, responsible for the agricultural insurance; agricultural insurance agency Business insurance company insured by the government, farmers and insurance companies to set up agricultural subsidies; venture capital fund for high-tech agricultural project investment. Four is to establish a multi body, multi form guarantee institutions, and effectively solve the difficulties of peasant households and rural SMEs loan guarantees. We should encourage the government funded various credit guarantee institutions and the existing commercial guarantee institutions to develop the rural guarantee business; and encourage farmers and small producers, township enterprises create small and medium-sized agricultural loan Guarantee Corporation, and give appropriate preferential tax during a certain period of time. Actively explore warehouse receipts pledge, farm tools, livestock, crop harvest, interest pledge, and other means of guarantee.

\section{Reasonably Guide the Healthy Development of Rural Folk Finance}

For a long time, rural informal finance has limited capacity to meet the needs of farmers and rural enterprises. Private financial support for the rural economy has played a certain role in the development of rural economy. In the development of rural financial market diversification and competition, the role of folk finance can not be ignored. The key is how to guide the orderly and 
healthy development, it is becoming a harmonious part of a rural financial system. One is not to interfere in the mutual interest free borrowing ; Secondly, it is important to encourage and guide private lending interest to take formal contract, prevent lending disputes, and resolutely curb the spread of usury, mitigate its negative effects; it is also needly to relax the market access conditions, give some rural folk financial organization legal status, guidance and supervision in the supervision department.

\section{Development of Financial Products Suitable for the Construction of New Countryside}

At present, although the rural areas in the less developed areas are still dominated by peasant households, today's farmers are moving towards a new era. The traditional planting and processing households are growing to large farmers, agricultural orders, migrant workers, business farmers and small processing households change. Its business scope has penetrated into agricultural products processing, manufacturing, transportation, commodity circulation and various types of industrialization and other fields. Subsequently, the demand for funds of farmers is also diversified, so it is necessary to create new financial products and services from the perspective of training new farmers, developing modern agriculture and building new countryside.

\section{Conclusion}

Building a new socialist countryside is an arduous and complex historical task. Rural financial construction is a rather difficult system engineering. The construction of new rural financial system must be in accordance with time to speed up the Party Central Committee and the State Council on promoting the construction of new socialist countryside and puts forward to solve rural financial system reform spirit, make clear the functions of financial institutions in the rural financial market, the adjustment of rural financial structure, improve the overall function of the rural financial system. The central bank should strive to promote the reform, improve service, to create a favorable policy environment and financial security for the reform and development of rural financing environment, promote the healthy development of rural finance and should play a role in promoting the construction of new socialist countryside.

\section{References}

[1]Jana Jarábková,Lubica Majstríková,Tomáš Kozolka. Financial Supporting Tools of Rural Tourism Development in Nitra Self-Governing Region[J]. European Countryside,2016,82.

[2]Yuxia ZHANG. Chinese Rural Financial Exclusion[J]. Management Science and Engineering,2013,74.

[3]Lei Zhang. Research on Financial Support for Rural Economic Development in China[J]. Applied Mechanics and Materials,2014,3512651.

[4]McAtee Robin E,Beverly Claudia J. A Method for Analyzing the Financial Viability of a Rural Provider Based Geriatric Clinic.[J]. Journal of Ambulatory Care Management,2005,283.

[5]P. I. Otiman. Rural Development and Agriculture:Oportunities for Minigating the Financial and Economic Crisis and Resuming Economic Growth[J]. Lucrări Ştiinţifice,2009,XI1.

[6]H. Young Baek,Dong-Kyoon Kim,Joung W. Kim. Management Earnings Forecasts and Adverse Selection Cost: Good Vs Bad News Forecast[J]. International Journal of Accounting and Information Management,2008,16(1).

[7]Stephen J. Ciccone,Ahmad Etebari. Analyst Earnings Forecast Trends in Pacific Rim Countries[J]. Managerial Finance,2004,30(7).

[8]Toward an Understanding of the Risky Choice Behavior of Professional Financial Analysts[J]. James E. Hunton, Ruth Ann McEwen,Sudip Bhattacharjee. Journal of Behavioral Finance. 2001(4).

[9]3 Methods to Forecast the Revenue Budget.[J]. Monahan J T. Hospital Financial Management. 1978(11).

[10]Statistical Methods to Forecast Volume of Service for the Revenue Budget.[J]. Donlon V W. Hospital Financial Management. 1975(4). 
[11]Prediction of Financial Revenue in Guizhou Province Based on Improved Grey Combination Models[J]. Hui Liu. Applied Mechanics and Materials. 2014(551).

[12]The Decision to Voluntarily Provide an IPO Prospectus Earnings Forecast[J]. Chris M. Bilson,Richard A. Heaney,John G. Powell,Jing Shi. Applied Financial Economics Letters. 2007(2).

[13]Analyst Earnings Forecast Revision Activity Around Profit Warnings Across Four European countries[J]. François Aubert, Waël Louhichi. Journal of Applied Accounting Research. 2015(1). 